\title{
Distribution and Variability of Pseudocercospora griseola in Uganda
}

\author{
G. Ddamulira ${ }^{1}$, C. Mukankusi ${ }^{2}$, M. Ochwo-Ssemakula ${ }^{1}$, R. Edema ${ }^{1}$, P. Sseruwagi ${ }^{3} \&$ P. Gepts ${ }^{4}$ \\ ${ }^{1}$ Department of Agricultural Production, Makerere University, Kampala, Uganda \\ ${ }^{2}$ International Centre for tropical Agriculture, P. O. Box 6247, Kampala, Uganda \\ ${ }^{3}$ Mikocheni Agricultural Research Institute P. O. Box 6226, Dar es Salaam, Tanzania \\ ${ }^{4}$ University of California, Davis, USA \\ Correspondence: G. Ddamulira, Department of Agricultural Production, Makerere University, P. O. Box 7062, \\ Kampala, Uganda. E-mail: ddamuliragab@yahoo.co.uk
}

Received: January 17, 2014 Accepted: March 21, 2014 Online Published: May 15, 2014

doi:10.5539/jas.v6n6p16 URL: http://dx.doi.org/10.5539/jas.v6n6p16

\begin{abstract}
Pseudocercospora griseola the casual pathogen for angular leaf spot (ALS) on common bean (Phaseolus vulgaris) is highly variable with many different races occurring in different agro-ecological zones. Therefore, for an effective breeding program, there is a need to continuously monitor the distribution and variability of the pathogen as a means of guiding breeders on which races to target. A study was conducted to assess the incidence, severity and variability of $P$. griseola in bean growing districts of Dokolo, Lira, Apac, Sironko, Mbale, Rakai, Lwengo, Bukomansibi, Kabale and Kisoro in Uganda. Forty five out of 80 isolates collected were tested on a set of 12 international bean differentials cultivars for ALS. Molecular markers were also used to elucidate the variability among isolates. In all districts, ALS was found wide spread with a mean incidence of $49.9 \%$. Dokolo district had the highest disease incidence and severity, while Kisoro registered the lowest values respectively. In terms of altitude, incidence $(60 \%)$ and severity $(45 \%)$ were high for bean fields located between $1000-1200 \mathrm{~m}$ and low disease incidence (33.6\%) and severity $(20.7 \%)$ for fields lying above $1500 \mathrm{~m}$. The standard differential cultivars and molecular markers defined 12 pathotypes and 30 haplotypes respectively. These belonged to Middle America and Andean group with considerably high level of diversity. Our findings indicated the presence of ALS in Uganda with high incidence, severity and variability across districts and altitudes. Hence strategic interventions involving integrated disease management and breeding for durable resistance are required to manage the disease.
\end{abstract}

Keywords: Pseudocercospora griseola, incidence, severity \& variability

\section{Introduction}

Angular leaf spot (ALS) caused by Pseudocercospora griseola Sacc. Crous and U. Braun is among the most destructive disease of common bean (Phaseolus vulgaris) in tropical and subtropical regions (Allorent \& Savary, 2005). The disease is also a major constraint to bean production in the Great Lakes Region (Kenya, Uganda, Tanzania and Rwanda) where bean growing is popular (Wortmann et al., 1998). The wide disease spread within this region is attributed to biotic and abiotic factors. Some of the biotic factors include; use of susceptible cultivars, uncertified seed and poor field sanitary practices (Wagara et al., 2003). On the other hand, abiotic factors, such as intermittent dry-wet and warm-cool weather which characterise weather patterns in most bean growing areas in Uganda, accelerate the pathogen sporulation process (Correa-Victoria et al., 1989). The dry-wet conditions coupled with poor disease management practices encourage $P$. griseola proliferation leading to heavy infestation (Celleti, 2006).

Despite the existence of ALS, its control is complicated by pathogenic variation of the fungus. Based on morphological and molecular markers, two gene pools of origin for common bean have been defined namely; the Andean and Middle American. The Andean isolates are pathogenic to large seeded beans while the Middle Americans are pathogenic to both small and large seeded beans (Pastor-Corrales et al., 1998). Nonetheless $P$. griseola pathotype structure might also be associated with the compatibility of cultivated bean genotypes. Whereas most large seeded commercial varieties in Uganda are susceptible to ALS (Namayanja et al., 2006), cultivars such as AND 277, G5686 and Mexico 54 have been identified as valuable sources of resistance (Nietsche et al., 2001; Pastor-Corrales et al., 1998; Aggarwal et al., 2004). A number of studies have demonstrated that the level of variability among and within $P$. griseola population is considerably high, even though the sexual form of the 
fungus has not been found (Leibenberg \& Pretorius, 1997). Previous studies demonstrated variation in pathogenicity of fungal isolates, as 53,13 and 50 different pathotypes described among 54,30 and 112 isolates that where obtained from Africa, Brazil and Central America respectively (Busogoro et al., 1999; Nietsche et al., 2001; Mahuku et al., 2004a). Though ALS has been identified to occur in Uganda, the pathotype structure of the fungus remains unknown and probably as a consequence of this there is hardly any commercial cultivar either tolerant or resistance which has been developed. In fact this is evidenced by $50 \%$ yield loss due to ALS reported among commercial varieties in Uganda (Opio et al., 2001).

In countries such as Brazil and Argentina where ALS also occur, yield loss resultant of ALS has been minimised through practising crop rotation, using certified seed and fungicide (Sartorato, 2002; Stenglein et al., 2003). Currently such control measures are not viable in Uganda due to limited land holdings per farmer hence low investment in crop production as an enterprise, poor access to and high cost of quality seed and fungicides (Mwangombe et al., 2007). In such a situation, breeding for resistance is seen as the most practical and economic approach to manage ALS under farmers' condition. However, the process of designing an effective ALS breeding program requires precise and accurate knowledge on population dynamics and spatial and temporal distribution of $P$. griseola (Stenglein et al., 2003). Past studies have indicated that many races of $P$. griseola occur and vary in time and space; a bean cultivar which is resistant in one location, season or year may be susceptible in another (Aggarwal et al., 2004). But there is still limited information on pathogen distribution and variability in Uganda (Mahuku et al., 2004) hindering breeding for ALS resistance. Therefore a study to understand the pathogen distribution and variability of $P$. griseola as the first step in designing strategic breeding interventions to develop resistance against ALS in Uganda (Sartorato, 2004) is required.

Several techniques have been used to study the distribution and variability of fungi; some of them include; disease surveys, differential cultivars and molecular techniques (Sartorato, 2004; Sebastian \& Balatti, 2006). Disease surveys allow pathogen distribution to be determined in terms of incidence, severity, spatial and temporal distribution. Such surveys have been used in Kenya to determine ALS incidence and severity (Mwang'ombe et al., 2007), and generate information needed to design integrated disease management strategies (Wagara et al., 2003). On the other hand, $P$. griseola virulence is assessed based on reaction of isolates on a standard differential set of 12 common bean cultivars established during the International angular leafspot workshop hosted by International Centre for Tropical Agriculture (CIAT) in 1995. In this technique, a binary system based on the position of each cultivar within the series is used to define the virulence level of isolates under study (Pastor-Corrales et al., 1998). Use of differential cultivars generates a true picture of virulence structure and reveals the pathogen properties related to host selection effect on the pathogen population (Sebastian and Balatti, 2006). But the major limitation for this method is its heavy dependence on environmental conditions (Kolmer et al., 1995).

However, challeneges in using differential technique has been overcome, through the use of molecular techniques as alternative options for detecting variability in pathogen populations. Available genetic markers such as random amplified microsatellite (RAMS), repetitive sequences such as enterobacterial repetitive intergenic consensus sequence (ERIC) and repetitive extragenic palindromic (REP) which have all indicated how P. griseola is extremely diverse (Sebastian \& Balatti, 2006). Such makers have been reported to be reliable, reproducible when used to assess fungus strain diversity especially when combined with computer-assisted data analysis (Louws et al., 1999). Depending on the reliability, markers have been previously used to determine genetic variation of $P$. griseola and divided it into two Andean and middle American groups (Pastor-Corrales et al., 1998). The existence of two groups suggest that developing durable resistance requires incorporation of resistance genes from Andean into a mesoamerican cultivar, a process best complemented by a clear understanding of how variable P.griseola is. Hence, the study aimed at assessing the distribution and variation of $P$. griseola isolates from Uganda using both the differential cultivar and molecular techniques in order to facilitate breeding against ALS resistance.

\section{Materials and Methods}

\subsection{Disaease Incidence and Severity}

An observation survey was conducted in 10 districts of Uganda; Mbale, Sironko, Lira, Dokolo, Apac, Bukomansibi, Lwengo, Rakai, Kabale and Kisoro. The districts were selected based on their bean production intensity and location in terms of altitude. Dokoro, Lira and Apac districts represented low altitude areas (1000-1200 metres above sea level m.a.s.l), Bukomansibi, Lwengo, Rakai mid altitude (1200-1500 m.a.s.l) and Mbale, Sironko, Kabale, Kisoro high altitude (>1500 m.a.s.l). Observations were made during August 2011 for Eastern and Northern and December 2011 for Central and South Western districts respectively. This represented mid- podding stage for beans when ALS epidemics best manifests itself (Allen et al., 1998). Random sampling was used to select 20 fields that were $5 \mathrm{~km}$ apart per district.Within fields disease incidence and severity was assessed 
by taking a transact walk across the field, three sites which were $10 \mathrm{~m}$ apart along the transact were earmarked and 20 plants observed for presence of ALS symptoms. Disease incidence was expressed as the percentage of infected plants over the 20 plants picked, while disease severity was estimated as percent leaf area diseased ( $0 \%$ plants with no visible disease symptoms; $2 \%$ presence of a few small non-sporulating lesions on the upper leaf surface; $5 \%$ plants with several small lesions but with limited sporulation; $10 \%$, plants with abundant and generally large sporulating lesions covering the leaf surface and associated with chlorosis and necrosis; $25 \%$ or more of leaf surface with large sporulating and often coalescing lesions, frequently associated with chlorosis resulting in severe and premature defoliation). For each sampled site a Global Positioning System (GPS) reading was taken to ascertain its location in terms of latitude, longitude and elevation. In addition, two diseased leaf sample sat each site were placed between two papers in a counter book, labelled and taken to the laboratory for pathogen isolation.

Table 1. Origin and pathotype nomenclature of Pseudocercospora griseola isolates used in this study

\begin{tabular}{|c|c|c|c|}
\hline Isolate code & Bean cultivar & District & Pathotype \\
\hline MB001 & Kanyebwa & Mbale & $21: 38$ \\
\hline MB014 & Wayirima & Mbale & $17: 23$ \\
\hline MB015 & Kaki & Mbale & $5: 55$ \\
\hline MB017B & Kanyebwa & Mbale & $15: 39$ \\
\hline MB020 & Kamwanyi & Mbale & $17: 23$ \\
\hline MB025 & Kamwanyi & Mbale & 17.23 \\
\hline MB023 & Kanyebwa & Mbale & $17: 23$ \\
\hline MB026 & Kanyebwa & Mbale & $17: 23$ \\
\hline MB024 & Kamwanyi & Sironko & $17: 23$ \\
\hline D0041 & Mudugavu & Apac & $41: 6$ \\
\hline D0047 & Mudugavu & Apac & $15: 39$ \\
\hline D0051 & Mudugavu & Apac & $15: 39$ \\
\hline D0053 & Mudugavu & Apac & $15: 39$ \\
\hline D0056 & Mudugavu & Apac & $15: 39$ \\
\hline D0058 & Mudagavu & Dokolo & $17: 23$ \\
\hline L0064 & Mudugavu & Lira & $17: 23$ \\
\hline L0065 & Mudugavu & Lira & $17: 23$ \\
\hline L0068 & Mudugavu & Lira & $17: 23$ \\
\hline L0069 & Owakwak & Lira & $5: 6$ \\
\hline L0070 & Mudugavu & Lira & $17: 23$ \\
\hline L0066 & Mudugavu & Lira & $15: 39$ \\
\hline L0072 & Mudugavu & Lira & $15: 39$ \\
\hline L0073 & Mudugavu & Lira & $5: 30$ \\
\hline MA081D & Nambale & Masaka & $17: 39$ \\
\hline RA06/2 & Kanyebwa & Rakai & $17: 39$ \\
\hline RW032C & White beans & Lwengo & $5: 30$ \\
\hline KA036 & Kakira & Kabale & $13: 13$ \\
\hline KA033 & Kakira & Kabale & $13: 55$ \\
\hline KA041C & Kakira & Kabale & $17: 39$ \\
\hline KA034C & Bishara & Kabale & $5: 31$ \\
\hline KA044 & Bishara & Kabale & $13: 55$ \\
\hline KA045 & Bishara & Kabale & $13: 13$ \\
\hline KA047 & Biashara & Kabala & $5: 31$ \\
\hline KA0 48C & Bishara & Kabale & $5: 55$ \\
\hline KA060 & Bishara & Kabale & $61: 63$ \\
\hline KA084 & Muzahura & Kabale & $21: 38$ \\
\hline KIS039B & Muzahura & Kisoro & $15: 39$ \\
\hline KIS039D & Sugar & Kisoro & $21: 38$ \\
\hline KIS061A & White beans & Kisoro & $21: 38$ \\
\hline KIS062 & Sugar & Kisoro & $5: 30$ \\
\hline KIS048 & Sugar & Kisoro & $5: 30$ \\
\hline KIS064B & Sugar & Kisoro & $17: 39$ \\
\hline KIS066 & Sugar & Kisoro & 41.6 \\
\hline KIS075 & Sugar & Kisoro & $5: 6$ \\
\hline KIS074 & Sugar & Kisoro & $17: 39$ \\
\hline
\end{tabular}




\subsection{Virulence Determination}

\subsubsection{Fungal Isolation and Inoculum Preparation}

Forty five single spore $P$. griseola isolates obtained from 10 bean growing districts of Uganda were isolated from the diseased bean leaves collected during the observatory survey (Table 1). Two additional characterised isolates (Middle American and Andean) obtained from CIAT at Kawanda were also included to elucidate the relationship between isolates belonging to the middle American and those from Andean among the Ugandan isolates. Isolation, monosporic culture production and inoculums preparation were done according to (Pastor-Corrales et al., 1998). Spore concentration in the inoculums was estimated using a haemocytometer and adjusted to a final concentration of $2 \times 10^{4}$ conidia $\mathrm{ml}^{-1}$ using sterile distilled water.

\subsubsection{Inoculation and Pathotype Determination}

In order to determine the pathotype of each isolate a set of 12 differential cultivars consisting of six Andean (Don Timoteo, G 11796, Bolon Bayo, Montcalm, Amendoin, G 5686) and six Mesoamerica (Pan 72, G 2858, Flor de Mayo, Mexico 54, BAT 332, Cornell 49-242) were used . Five seeds of each differential cultivar were planted in 5-litre buckets containing black soil, manure and sand in a ratio of 3:1:1. The experiment was laid out in randomised complete block design with three replications. The 21-days old bean plants were spray-inoculated with inoculums and kept in a humid chamber at $22-28{ }^{\circ} \mathrm{C}$ and $95 \%$ relative humidity. Four days after inoculation, plants were transferred into the screen house and watered regularly.

Disease symptoms on the inoculated plants were evaluated using a CIAT 1-9 visual scale (Schoonhoven \& Pastor-Corrales, 1987) for 21 days at an interval of three days, described as follows: 1, plants with no visible disease symptoms; 3 , presence of a few small non-sporulating lesions that cover approximately $2 \%$ of the leaf surface; 5 , plants with several small lesions with limited sporulation and covering approximately $5 \%$ of leaf surface; 7, plants with abundant and generally large sporulating lesions covering approximately $10 \%$ of leaf surface and associated with chlorosis and necrosis; $9,25 \%$ or more of leaf surface with large sporulating and often coalescing lesions, frequently associated with chlorosis resulting in severe and premature defoliation.

Pathotypes were defined by rating scores of 1-3 to be incompatible or resistant, while ratings $>3$ were compatible or susceptible. Pathotype designation was executed by adding binary values of the differential genotypes that were compatible with the respective $P$. griseola isolate. For instance, for pathtype 15:39 (virulence phenotype abcdef-ghijkl) in Table 4, the first value was obtained by adding the binary values of the susceptible Andean differential genotype abcdef $(1+2+4+8=15)$ and the second value was obtained by adding the binary values of the susceptible Mesoamerica genotypes ghijkl $(1+2+4+32=39)$ in table 4 (Pastor- Corrales et al., 1998). For consistent results, the experiment was repeated twice.

\subsubsection{DNA Extraction and Primer Analysis}

The mycelium used in DNA extraction was generated on V8 agar growth media by cutting three disks of $1.5 \mathrm{~mm}$ diameter on the edges of actively growing fungi and inoculated on growth media contained in Erlenmeyer flasks $(250 \mathrm{ml})$. The cultures were placed on a rotary shaker $(120 \mathrm{rpm})$ at room temperature for 14 days. Mycelium was harvested through filtration with a cheese-cloth, washed in sterile deionised water, freeze- dried and stored at $-24^{\circ} \mathrm{C}$. DNA was extracted according to Mahuku, 2004b and quantified using a NanoDrop 2000c spectrophotometer (Thermo Scientific, Waltham, MA). The DNA was adjusted to a standard concentration of 10 $\mathrm{ng} / \mu \mathrm{l}$ before used in the PCR reaction. To analyse the primers, four random amplified microsatellites and five conserved sequences (Table 2) were used to amplify the fungal DNA extracted. The PCR reactions were carried out in $20 \mu$ l volumes containing $1 \times$ DNA polymerase buffer $(100 \mathrm{mM}$ Tris- $\mathrm{HCl}, 400 \mathrm{mM} \mathrm{KCl}, 15 \mathrm{mM} \mathrm{MgCl}$, $\mathrm{pH}$ 9.0), $3 \mathrm{mM} \mathrm{MgCl}_{2}, 0.4 \mathrm{mM}$ dNTPs, $1 \mu \mathrm{M}$ of each primer, $0.3 \mathrm{U}$ Taq DNA polymerase (Bioneer Inc. Korea) and $50 \mathrm{ng}$ of genomic DNA. A water control (DNA replaced with sterile water) was included with each set of 10 isolates. In additional DNA from isolate RU7 whose PCR reaction was known was also included as a positive PCR control. DNA amplification was performed in a Mycycler thermal cycler (Bioneer Inc, Korea) under a program of one cycle at $94{ }^{\circ} \mathrm{C}$ for $5 \mathrm{~min}$, followed by 35 cycles at $94{ }^{\circ} \mathrm{C}$ for $20 \mathrm{~s}, 50^{\circ} \mathrm{C}$ for $40 \mathrm{~s}$ and $65^{\circ} \mathrm{C}$ for 8 min and a final 16 min extension at $65^{\circ} \mathrm{C}$ (Table 2). The DNA amplicons were electrophoresed in $1.5 \%$ agarose gel for $1 \mathrm{~h}$ at $90 \mathrm{~V}$ in 1XTris-borate-EDTA buffer ( $89 \mathrm{mM}$ Tris base, $89 \mathrm{mM}$ boric acid-borate and $2 \mathrm{mM}$ EDTA pH 8.0$)$ and later stained for $20 \mathrm{~min}$ in $0.5 \mu \mathrm{g} / \mathrm{ml}$ ethidium bromide. Gel images were captured using the GeneSnap gel documentation system (SynGene, Frederick MD). 
Table 2. Sequences and annealing temperatures of RAMS and conserved primers used to amplify $P$. griseola DNA

\begin{tabular}{llc}
\hline Primer & Sequence $\left(5^{\prime}\right.$ to $\left.3^{\prime}\right)$ & Annealing temperature $\left(0^{\circ} \mathrm{C}\right)$ \\
\hline RAMS 4 & AGGGTGTGTGTGTG & 40 \\
RAMS 2 & TGCCGAGCTG & 40 \\
RAMS 5 & GGGTAACGCC & 40 \\
RAMS 6 & GTGATCGCAG & 40 \\
BOX A1R & CTACGGCAAGGCGACGCTGACG & 50 \\
ERIC 1R & ATGTAAGCTCCTGGGGAT & 50 \\
ERIC 2 & AAGTAAGTGACTGGGGGTGAGC & 50 \\
REP1R & IIIICGICGICATCIGGC & 40 \\
REP 2 & ICGICTTATCIGGCCTAC & 40 \\
\hline
\end{tabular}

\subsection{Statistical Analysis}

A homogeneity test was performed according to Cochran's test to assess the difference in disease scores between the two experimental repeats. The test revealed no significant $(\mathrm{P}>0.05)$ differences in disease scores for the two repeats and the data was pooled. In additional, Kurtosis-Skew tests were conducted on disease incidence and severity data and found to be significantly different from the normal. To improve on the non-normality arising from real observed data points the data was transformed using arcsine transformation of arcsine percentage (Gomez \& Gomez, 1984) and analysed using in Genstat edition 14( Payne et al., 2011). Incidence and severity means were separated using Fisher's protected Least Significant Difference (LSD) test at $\mathrm{P}<0.05$ ). The incidence and severity maps were developed using survey data points that were geo-referenced with a GPS and occurrence and severity means generated from the analysis. Correlation between occurrence and severity means was done according to Payne et al. (2011). Data points were transformed into a point map using Ilwis 3.2 software (Toxopeus, 1997) and the map exported and visualised in Arc View ${ }^{\circledR}$ GIS3.2 software (Rockware Inc).Virulence and molecular data analysis was done separately. Isolate virulence was determined by considering each differential as a marker and information on virulence phenotype generated by considering incompatible interaction (rating $\leq 3$ ) as absence of a virulence(-) and compatible interactions (rating > 3) as presence (+). However, for molecular data, markers were scored as either (1) for the presence of a band or (0) absence of the band. Only strong and reproducible bands were scored and weak ones discarded. Genetic similarities between all the pairs of isolates were computed using; S= Jaccard coefficient (Sneath \& Sokal, 1973) in DARwin5. Dissimilarities were computed as genetic distance $=1-\mathrm{S}$ and based on this data a dendogram was constructed by un-weighted pair group method with arithmetic mean (UPGMA) hierarchical clustering using MEGA 5.0. The gene diversity across all loci was estimated (Nei, 1987).

\section{Results}

\subsection{Disease Incidence}

Angular leaf spot incidence was variable among districts studied and it also differed significantly $(\mathrm{P}<0.05)$ across different altitudes. The highest disease incidence was recorded in Dokolo, Lira and Apac districts while Kisoro registered the lowest incidence (Figure 1). Disease incidence in Dokoro, Lira and Apac districts ranged between 59.5-69.5\%, while in Kisoro it was below 15\%. Moderate disease incidence ranging between $36.5-49.5 \%$ was observed in the central districts of Bukomansibi, Lwengo and Rakai, but disease incidence above $49.5 \%$ was observed in Mbale and Sironko districts (Figure 1).

\subsection{Disease Severity}

Angular leaf spot severity varied among the surveyed districts. Similarly, ALS severity was highest in Dokolo and lowest in Kisoro districts (Figure 2). The high ALS severity in Dokolo was observed to be accompanied with heavy leaf defoliation before reaching physiological maturity. Lira and Apac equally had high disease severity, followed by Mbale and Sironko. A strong positive correlation $(\mathrm{r}=0.88, \mathrm{P}<0.001)$ was observed between disease incidence and severity across districts indicating that two disease parameters were dependent on one another. 


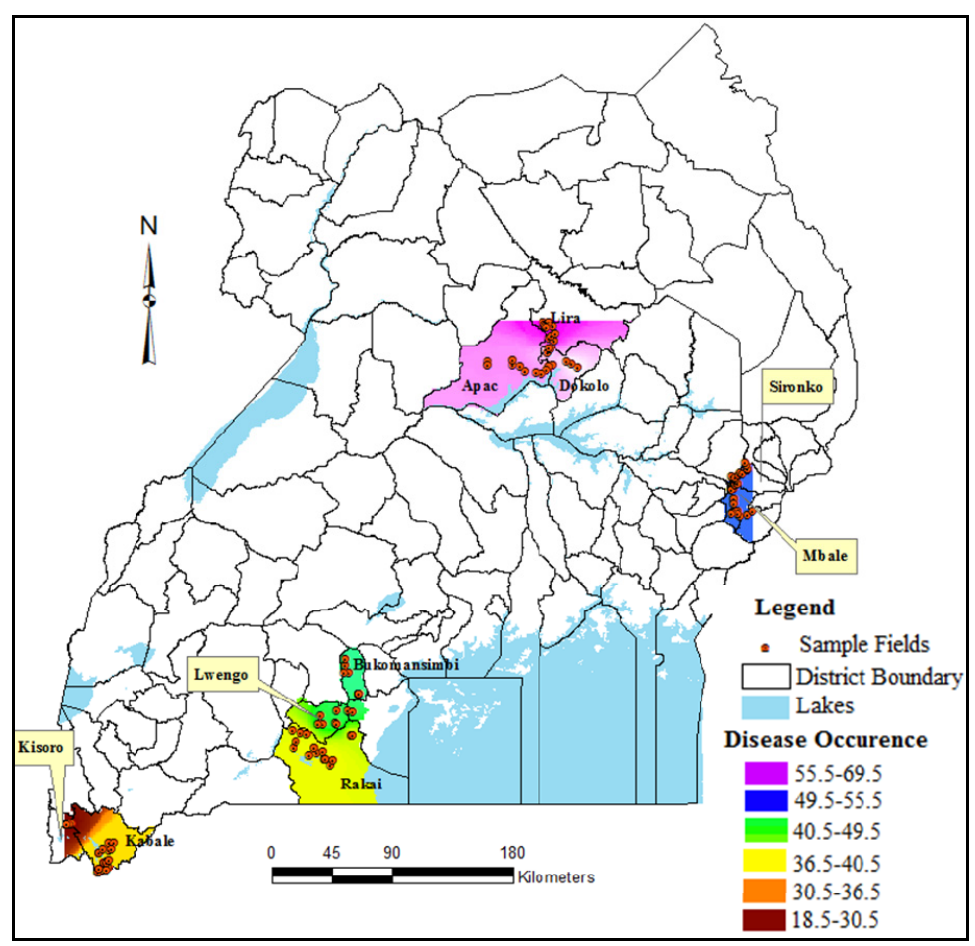

Figure 1. Incidence of $P$. griseola in ten bean growing districts of Uganda

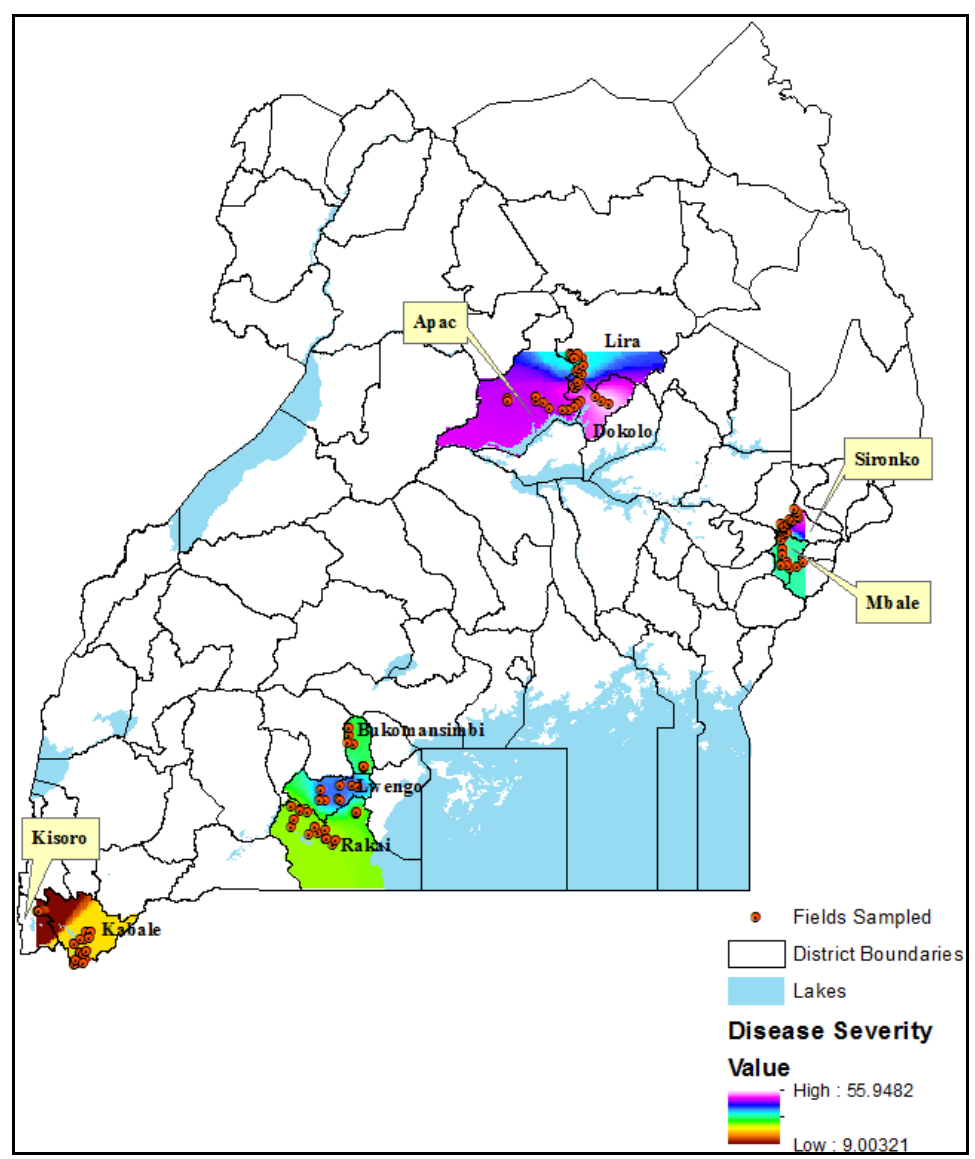

Figure 2. Severity of $P$. griseola in ten bean growing districts of Uganda 
Table 3. Incidence and severity of P.griseola at three different altitudes in Uganda

\begin{tabular}{lll}
\hline Altitude M (a.s.l) & Incidence (\%) & Severity (\%) \\
\hline $1000-1200$ & $60.0^{\mathrm{c}}$ & $45.0^{\mathrm{c}}$ \\
$1200-1400$ & $45.4^{\mathrm{b}}$ & $35.7^{\mathrm{b}}$ \\
$>1500$ & $33.6^{\mathrm{a}}$ & $20.7^{\mathrm{a}}$ \\
Mean & 46.3 & 33.8 \\
LSD $_{(0.05)}$ & 2.4 & 3.0
\end{tabular}

Figures followed by the same letter indicate lack of significance while those with same letter indicate significant difference.

Angular leaf spot incidence and severity varied significantly $(\mathrm{P}<0.05)$ across altitudes (Table 3$)$. Low altitude (1000-1200 m) areas had the highest disease incidence and severity followed by mid altitude (1200-1400 m). High altitude (above $1500 \mathrm{~m}$ ) areas exhibited the least disease incidence and severity.

\subsection{Virulence}

Pseudocercospora griseola pathotypes are often defined based on pathogenicity reaction to a set of 12 bean differential cultivars or molecular markers. In this study, the reaction of 45 P. griseola isolates on differential cultivars revealed the existence of pathogenic variability in this fungus. In total 12 pathotypes were defined out of the 45 isolates studied (Table 4). Most isolates where pathogenic to both Andean and Mesoamerica differentials with only two isolates that were more pathogenic to Andean than Mesoamerica differentials (Table 4). Based on isolates' pathogenic reactions on the differentials, 43 isolates were classified as Middle America and two as Andean groups respectively. Pathotype 61:63 was compatible with eleven differentials tested, while 17:23 and 21:39 were the most prevalent in areas studied (Table 1). It was worth noting that the most prevalent pathotypes (17:23 and 21:39) identified in this study had not been previously reported in Uganda. Pathotype 5:55 was observed to occur only in high altitude districts (Table 1).

Table 4. Response of a set of bean differential cultivars to inoculation with 45Pseudocercospora griseola isolates collected from Uganda

\begin{tabular}{|c|c|c|c|c|c|c|c|c|c|c|c|c|c|}
\hline \multicolumn{6}{|c|}{ Andean group $^{a}$} & \multicolumn{6}{|c|}{ Mesoamerican group $^{b}$} & \multirow[t]{3}{*}{ Pathotype $^{c}$} & \multirow[t]{3}{*}{ Number of isolates } \\
\hline $\mathrm{a}$ & $\mathrm{b}$ & $\mathrm{c}$ & $\mathrm{d}$ & $\mathrm{e}$ & $\mathrm{f}$ & $\mathrm{g}$ & $\mathrm{h}$ & $\mathrm{I}$ & $\mathrm{j}$ & & 1 & & \\
\hline 1 & 2 & 4 & 8 & 16 & 32 & 1 & 2 & 4 & 8 & 16 & 32 & & \\
\hline+ & - & + & - & + & - & + & + & + & - & - & + & $21: 39$ & 8 \\
\hline+ & - & - & - & + & - & + & + & + & - & - & + & $17: 39$ & 5 \\
\hline+ & - & - & + & - & + & - & + & + & - & - & - & $41: 6$ & 2 \\
\hline+ & - & + & - & - & - & + & + & + & + & + & - & $5: 31$ & 2 \\
\hline+ & - & + & - & + & - & + & + & + & - & - & + & $21: 38$ & 4 \\
\hline+ & - & + & - & - & - & + & + & + & - & + & + & $5: 55$ & 2 \\
\hline+ & - & + & - & - & - & + & - & + & + & - & - & $13: 13$ & 2 \\
\hline+ & - & + & - & - & - & - & + & + & + & + & - & $5: 30$ & 4 \\
\hline+ & - & + & - & - & - & - & + & + & - & - & - & $5: 6$ & 2 \\
\hline+ & - & - & - & + & - & + & + & + & - & + & - & $17: 23$ & 11 \\
\hline+ & - & + & + & - & - & + & + & + & - & + & + & $13: 55$ & 2 \\
\hline+ & - & + & + & + & + & + & + & + & + & + & + & 61:63 & 1 \\
\hline
\end{tabular}

${ }^{\mathrm{ab}}$ Andean groups included cultivars: (a) Don Timoteo; (b) G 11796; (c) Bloom Bayo; (d) Montcalm; (e) Amendoin; (f) G 5686. Middle American group included cultivars: (g) Pan 72; (h) G 2858; (i) Flor de Mayo; (j) Mexico 54; (k) BAT 332; (1) Cornell 49-242. ${ }^{\text {C} P a t h o t y p e ~ d e s i g n a t i o n ~ i s ~ b a s e d ~ o n ~ t h e ~ s u m ~(b i n a r y ~ v a l u e s) ~ o f ~ b e a n ~ c u l t i v a r s ~ w i t h ~} 10$ scale value. $(+)$, Compatible reaction; (-), Incompatible reaction. All pathogenicity tests included three replicates per isolate. 


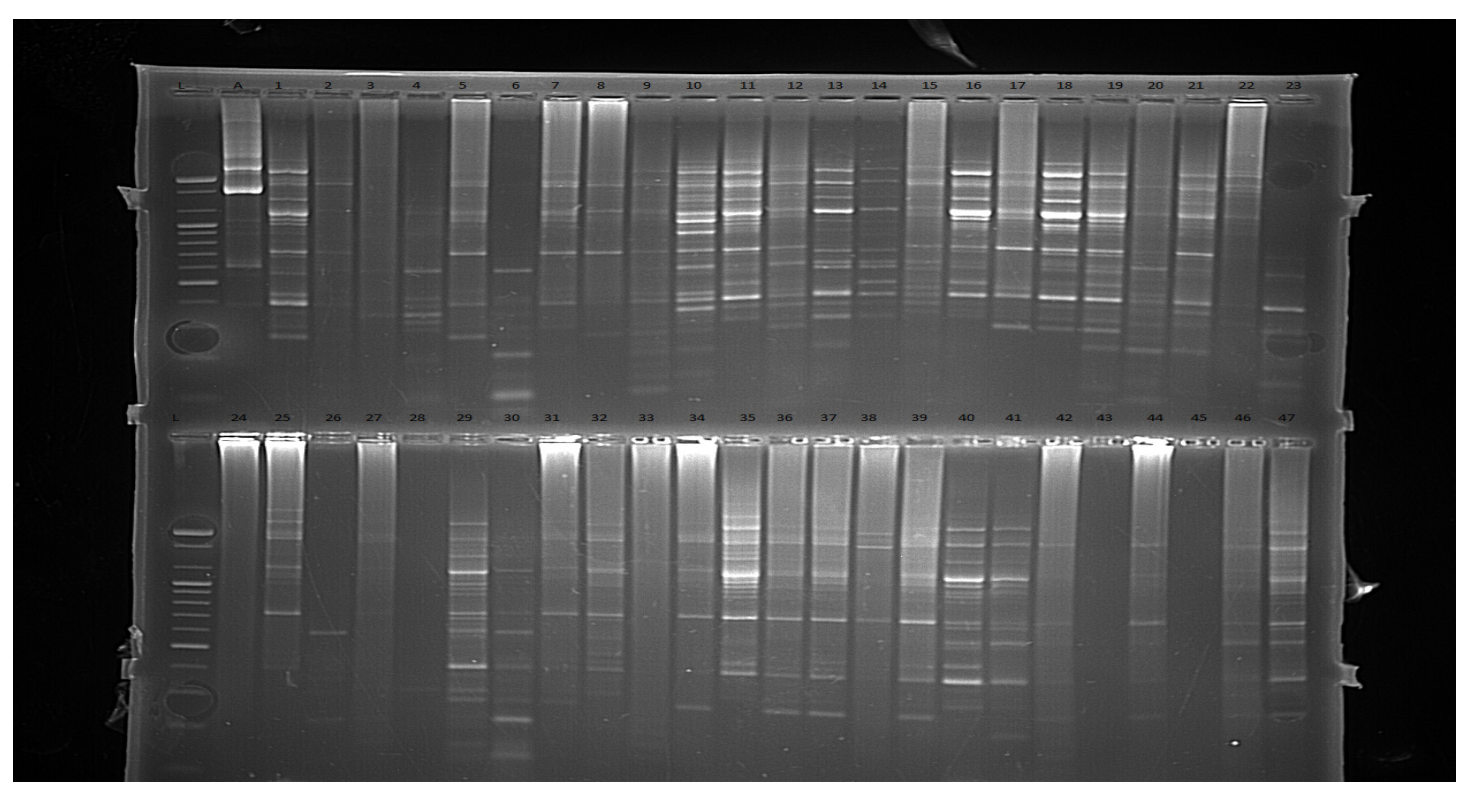

Figure 2. Amplification pattern of 47 Pseudocercospora griseola by repetitive extragenic palindromic (REP) and Random amplified micro-satellite (RAMS). Numbers on top represent the different isolates and the first lanes are DNA ladders, top bands (1-23) and bottom bands ( 24-27) represents amplication by REP and RAMS respectively

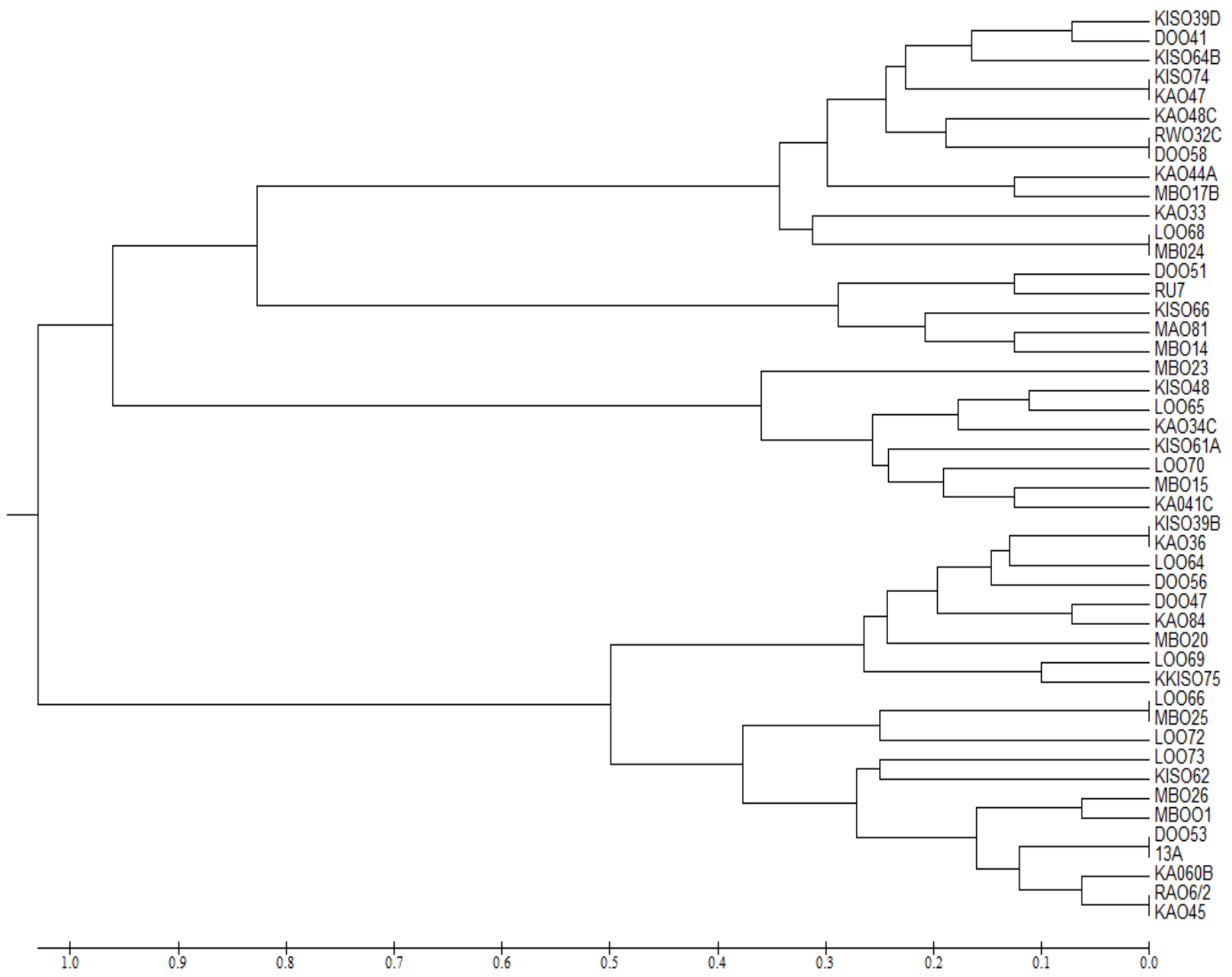

Figure 3. Dendogram generated based on RAMS and REP bands from 45Pseudocercospora griseola isolates from Uganda and 2 control isolates (RU7 and 13A) from CIAT, a representative group 1(Middle America) and representative group 2 (Andean) 


\subsection{Molecular Characterisation of P. griseola}

The pathogenic variability of $P$. griseola was analysed using 9 primers (Table 2).The isolates were grouped into two main clusters (Figure 3) with an average dissimilarity of 0.98. The Middle America and Andean groups constituted 25 and 20 isolates with one control for each group respectively. The two main groups were clustered into sub-groups; the Andean group constituted two sub-groups with average dissimilarity of $50 \%$ while the Middle America was divided into three sub-groups with $98 \%$ dissimilarity (Figure 3). Nonetheless, grouping of isolates was not based on their places of origin. The combination of markers used in the study identified 30 halophytes. Analysis of molecular variance (AMOVA) indicated that most of the variation resulted from genetic difference within Middle American and Andean group $(68.4 \% \mathrm{P}<0.05)$ rather than among main groups $(31.6 \%)$. The analysis of genetic diversity indicated that the pathogen was highly variable as indicated by the high polymorphic DNA bands shown in Figure 2. The genetic diversity of the entire population was 0.901 indicating the most isolates that constituted the population were different. The genetic diversity of the middle America and Andean were 0.450 (SD 0.098) and 0.443(SD 0.061), respectively.

\section{Discussion}

Generally our results confirmed the presence of ALS (P. griseola) in Uganda with varying pathotypes defined by phenotypic and molecular markers. The disease was found to occur at varying levels in all districts and altitude under study. This indicated that bean growing areas in Uganda have conditions that favour ALS development.

Most often ALS incidence and severity may be influenced by environmental factors and cropping practices. In our study environmental factors such as temperature and relative humidity possibly explained our findings. The low ALS incidence and severity in Kisoro may be attributed to cold temperatures. Among the districts surveyed, Kisoro is the coldest with temperatures as low as $10^{\circ} \mathrm{C}$ at night (Mugisha, 2008). Temperatures below $16^{\circ} \mathrm{C}$ which is the threshold for $P$. griseola infection and sporulation are known to retard ALS development (Inglis \& Hagedom, 1986). Similarly, high altitude $(>1500 \mathrm{~m})$ areas have high relative humidity above the threshold $(70 \%)$ for ALS development but they are characterised by cold temperatures which are also known to delay disease development (Inglis \& Hagedom, 1986). This was clearly exhibited in our findings by the low ALS incidence and severity recorded in Kabale, Kisoro and for high altitude areas which are characterised by cold conditions. On the other hand, the slightly high disease incidence and severity observed in high altitude areas of Mbale and Sironko when compared to other areas with similar altitude, indicated that cold temperatures alone might not be the only factor contributing to the low disease incidence and severity in all high altitude areas. But other factors such as bean cultivar type grown may also influence disease incidence. For instance we observed that most sampled fields in Mbale and Sironko had Kanyebwa a popular landrace in Uganda which is known to be highly susceptible to ALS (Namayanja et al., 2006). This probably explained the high disease incidence and severity observed in Sironko and Mbale compared to other high altitude areas studied.

On the other hand, the high ALS incidence and severity observed in Dokolo, Lira and Apac districts was partly attributed to bean cultivar preference. In Lira, Dokolo and Apac district farmers prefer small seeded beans (Nkonya, 2001). This is because small sized beans are comparable to pigeon pea a common delicacy in the region. Cultivar preference was evidenced in our findings by the majority samples collected from the three districts which were small seeded cultivars. The use of the same bean cultivar over time possibly led to pathogen adaptation to the commonly used small seeded cultivars and hence increased disease incidence and severity. Pathogen adaptation to popular bean cultivars has been previously reported by Sartorato (2004) in Goias state in Brazil where due to use of carioca bean type, ALS pathogen got adapted to carioca beans which led to increased cases of ALS in the region.

Angular leaf spot development is stimulated under temperature conditions of $18-22{ }^{\circ} \mathrm{C}$ and relative humidity of $70-100 \%$ (Stenglein et al., 2003). Such conditions are experienced in low altitude bean growing areas in Uganda (Mugisha, 2008). Similarly, disease samples were collected during the bean growing period when wet- and dry weather conditions are experienced in low altitude areas. Since these environmental conditions are known to favour ALS development (Correa-Victoria et al., 1989), they possibly explained the high disease incidence and severity observed in low altitude areas.

Most fungal pathogens that affect common beans are highly variable (Mahuku et al., 2009) and our study also exhibited the variability in $P$. griseola. Based on pathogenicity reaction of $P$. griseola on standard bean differential cultivars, the pathogen was divided into Middle American and Andean, corresponding to two gene pools of common beans. These results are consistent with Pedro et al. (2006) who reported that the causal organism for ALS underwent a micro evolution with its host, leading to two distinct groups; the middle-America and Andean. This was also evidenced in our study when the reactions of isolates to differentials of known Andean and middle-America origin were compared. Andeans isolates were mostly virulent to large-seeded (Andean) while the 
middle-America was more virulent to small seeded (Mesoamerican), based on this we confirmed that the standard differential cultivars categorised $P$. griseola isolates from Uganda into two major groups.

Among the two groups defined by differentials, most isolates belonged to Middle America group, yet in Uganda beans of Andean origin are the predominantly grown bean type. This indicated that some of the isolates that where recovered from Andean genotypes might have not been necessarily Andean type. This was possible because Middle America isolates are also known to attack bean genotypes from Andean gene pool (Araya et al., 2004). In addition previous studies by Guzman et al. (1995) in Malawi indicated the possibility of finding Middle America isolates on Andean host genotype. This implied that in Uganda the existing P. griseola race may not be dependent on the bean type predominantly grown.

The study identified pathotype 61:63 among Ugandan isolates which was compatible to eleven differential cultivars. Pathotype 61:63 overcomes resistant genes in 11 known sources of resistance that constituted part of the differential set. Similar pathotypes have been reported in Brazil and Argentina (Sartarota, 2002; Sebstian et al., 2006) and their presence in Uganda and other countries implies that new sources of resistance need to be identified regularly to mitigate resistance break down. On the other hand, pathotypes that overcome resistance in differential cultivars are potential candidate for use in screening germplasm against ALS by breeding programs.

The common occurrence of pathotypes 17:23 and 21:39, exhibited in the study indicated an overlap of pathotypes across bean production areas. Such pathotype overlap could possibly be as result of seed exchange which is a common practice among small holder farmers in Uganda (David et al., 2000). Due to high cost of certified seed farmers source seed from fellow farmers or informal markets whose supplies comes from different parts of the country. Such a seed system is reliable to transmission of different $P$. griseola races across bean production areas.

The occurrence of pathotype 5:55 in only highland areas could be attributed to complex interaction between environment and crop management practices rather than virulence. Crop management practices such as continued use of one cultivar overtime leads to adaptation of pathotypes to particular bean types (Sartorato, 2004). In Uganda farmers in highland areas prefer climbing beans to bush type due to their high yield and low disease pressure associated with cool environment (MAAIF, 2003). The continued use of climbing bean cultivars in highlands may be responsible for presence of pathotype 5:55 only in highlands which over time could have got adapted to climbing beans dominantly grown in highlands. However, this requires further validation studies. It was also worth noting that the frequently occurred pathotypes 17:23 and 17:39 where being reported for the first time in Uganda. This could have been attributed to previous studies which where continental or regional based without comprehensive countrywide studies covering all bean production areas across the country. For instance, among the 7 and 16 Ugandan isolates studied by Aggarwal et al. (2004) and Mahuku et al. (2002) under a regional study in eastern and southern Africa none of the isolates were in the same pathogenic class like 17:23, 17:39 identified in our study. In this study we studied 45 isolates from ten bean production districts and molecular analysis identified 30 haplophytes. This means that with more extensive isolate collection covering the whole country more pathogen variability could be revealed.

The genetic diversity of $P$. griseola fungus was studied based on molecular markers. At DNA level, high diversity was exhibited with markers defining 30 haplotypes compared to virulence which defined 12 pathotype. This was expected because molecular markers are unrelated with pathotype diversity (Sebastian et al., 2006) suggesting that isolates of the same pathotypes might not necessarily be closely related based on DNA analysis. These results are consistent with findings by Sicard et al. (1993) and Leibenberg and Pretorius (1997) who provided evidence that there is high haplotypic diversity in P. griseola. The high genetic differentiation among Andean and Middle America groups revealed a strong influence of host specialisation on the population structure of $P$. griseola. It also confirmed that the sub-groups of this pathogen are highly variable and structured along host gene pools (Pastor-Corrales et al., 1998). Genetic differentiation within each group was high (68.4\%), indicating that sufficient genetic diversity is being maintained in fungus. But the sources of genetic diversity observed among isolates were uncertain for a fungus like $P$. griseola with no sexual cycle reported (Leibenberg \& Pretorius, 1997). However, factors such as mutations, migration and parasexual (Anderson \& Kohn, 1995; Brown \& Wolfe, 1990; McDonald \& McDermott, 1993; Zeigler et al., 1995) can interact to create or maintain high levels of genetic diversity as observed in P. griseola. Zeigler et al. (1995) showed evidence that high levels of haplotypic diversity can be maintained in asexually reproducing fungi through parasexual reproduction. Chromosomal diversions, deletions and loss of chromosome segements (Kristler \& Miao, 1992), and the presence of transposons (Kempken $\&$ Kuck, 1998) all have the capacity to increase the diversity in fungi and contribute to high haplotypic diversity (Leibenberg \& Pretorius, 1997). Seed transmission of $P$. griseola has been adequately documented (Sartorato, 2000), and introductions of new haplotypes through contaminated seed cannot be ruled out as a source of high diversity (Leibenberg \& Pretorius, 1997). Since this study was unable to identify the actual cause of high 
differentiation, we therefore suggest that further research is undertaken to validate whether the observed population differentiation resulted the factors mentioned above.

The molecular results further revealed that isolate grouping was not based on places of origin. In most fungal pathogens, presence of genetically differentiated populations within the same location is as a result of geographical isolation or ecological niche preference (Klaassen et al., 2012). However, in our study P. griseola grouping based on place of origin was not observed probably because races from two gene pools can occupy the same ecological niche (Araya et al., 2004). Similar findings have been reported by several authors; Sebastian et al. (2006) reported that different pathotypes coexisted in the production or geographical areas in Argentina. In additional, findings by Sartorato, 2000 indicated isolates collected from the same location showed difference in their grouping pattern. This implied that different strategies that are not location specific should be employed when managing ALS in Uganda.

Several studies have reported high genetic variability of $P$. griseola defined by different markers. For instance, studies by Sartorato (2004) estimated high genetic variability of 96 P.griseola using RAPD markers though the grouping was not based on geographical origin. Other studies on estimation of genetic variability have been conducted by Sebastian and Balatti (2006) in Argentina; out of 45 P. griseola isolates a combination of ISSR and RAPD defined 18 halophytes. Similarly in Brazil Abdio et al. (2012) defined 27 halopytes out of the 27 isolates using ISSR markers, in our study a combination of RAMS and REP has revealed 30 halophytes indicating high variability among $P$. griseola isolates existing in Uganda. .

\section{Conclusion}

The study revealed the existence of $P$. griseola in Uganda. The disease is distributed in most bean growing districts and at different altitude. The variation in P. griseola was revealed by the existence of 12 pathotypes and 30 halophytes which were defined by standard bean differential cultivars and molecular makers. This exhibited the potential of standard differentials and molecular makers' ability to detect isolate polymorphism though molecular markers proved to detect more variation than differentials can. The variation exhibited by this pathogen indicates that different sources of resistance will be required to manage ALS. Hence concerted efforts are needed to develop broad resistance in Uganda. Our findings do not only provide fundamental information on the distribution of P.griseola in Uganda but also provided a basis onto which breeding strategies aiming at developing disease resistance can be built. Hence genetic variation observed can be used in breeding programs in developing appropriate varieties resistant to ALS.

\section{Acknowledgement}

The Research was supported by a grant from Regional Universities Forum for Capacity Building in Agriculture (RUFORUM), Carnegie Corporation, Borlaug and International Centre for Tropical Agriculture (CIAT).

\section{References}

Abadio, A. K. R., Lima, S. S., Santana, M. F., Salomão, T. M. F., Sartorato, A., Mizubuti, E. S. G., \& de queiroz, M. V. (2012). Genetic diversity analysis of isolates of the fungal bean pathogen Pseudocercospora griseola from central and southern Brazil. Genet. Mol. Res, 11, 1272-1279. http://dx.doi.org/10.4238/2012.May.14.1

Aggarwal, V. D., Pastor-Corrales, M. A., Chirwa, R. M., \& Buruchara, R. A. (2004). Andean beans (Phaseolus vulgaris L.) with resistance to the angular leaf spot pathogen (Phaeoisariopsis griseola) in southern and eastern Africa. Euphytica, 136(2), 201-210. http://dx.doi.org/10.1023/B:EUPH.0000030678.12073.a9

Allen, D. J., Buruchara, R. A., \& Smithson, J. B. (1998). Diseases of common bean. In D. J. Allen, \& J. M. Lenne' (Eds.), the Pathology of Food and Pasture Legumes (pp. 179-265). Walligford, CABI, UK.

Allorent, D., \& Savary, S. (2005). Epidemiology characteristics of angular leaf spot of bean: a systems analysis. European Journal of plant Pathology, 113, 329-341. http://dx.doi.org/10.1007/s10658-005-4038-y

Anderson, J. B., \& Kohn, L. M. (1995). Clonality in soil borne, plant- pathogenic fungi. Annu. Rev. Phytopathol, 33, 369-391. http://dx.doi.org/10.1146/annurev.py.33.090195.002101

Araya, C. M., Alleyne, A. T., Steadman, J. R., Eskridge, K. M., \& Coyne, D. P. (2004). Phenotypic and genotypic characterization of Uromyces appendiculatus from Phaseolus vulgaris in the Americas. Plant Disease, 88, 830-836. http://dx.doi.org/10.1094/PDIS.2004.88.8.830

Brown, J. K., \& Wolfe, M. S. (1990). Structure and evolution of a population of Erysiphe graminis f.sp. hordei. Plant Pathol, 45, 344-349. 
Busogoro, J. P., Jijakli, M. H., \& Lepoivre, P. (1999). Virulence variation and RADP polymorphism in African isolates of Phaeoisariopsis griseola Sacc.Ferr the casual agent of angular leaf spots of common bean. Eur. $J$ Plant Pathol, 105, 559-569. http://dx.doi.org/10.1023/A:1008707101645

Celetti, M. J., Melzer, M. S., \& Boland, G. J. (2006). Angular leaf spot of snap beans, Ministry of Agriculture Food and Rural Affairs Ontario, Canada.

Correa-Victoria, F. J., Pastor-Corrales, M. A., \& Saettler, A. W. (1989). Angular leaf spot. In H. F. Schwarts, \& M. A. Pastor-Corrales (Eds), Bean Production Problems in the Tropics (pp. 59-75). Cali, Colombia: Centro Internacional de Agricultura Tropical.

Crous, P. W., Liebenberg, M. M., Braun, U., \& Groenewald, J. Z. (2006). Re-evaluating the taxonomic status of Phaeoisariopsis griseola, the causal agent of angular leaf spot of bean. Stud. Mycol, 55, 163-173. http://dx.doi.org/10.3114/sim.55.1.163

David, S., Kirkby, R., \& Kasozi, S. (2000). Assessing the impact of bush bean varieties on poverty reduction in Sub-Saharan Africa: Evidence frown Uganda. Network on Bean Research in Africa, occasional Publication Series, No. 31, Centro Internacional de Agricultura Tropical, Kampala, Uganda.

Gomez, K. A., \& Gomez, A. A. (1984). Statistical Procedures for Agricultural Research (2nd ed.). Singapore: John Wiley and sons.

Guzm'an, P., Gilbertson, R. L., Nodari, R., Johnson,W. C., Temple, S. R., Mandala, D., ... Gepts, P. (1995). Characterization of variability in the fungus Phaeoisariopsis griseola suggests coevolution with the common bean (Phaseolus vulgaris). Phytopathology, 85, 600-607. http://dx.doi.org/10.1094/Phyto-85-600

Inglis, D. A., \& Hagedom, D. J. (1986). Temperature requirements by Isariopsis griseola for infection and disease development on red kidney beans. Ann. Rep. Bean Improv. Cooperative, 29-35

Kempken, F., \& Kuck, U. (1998). Transposons in filamentous fungi; facts and perspectives. Bioessays, 20 , 652-659. http://dx.doi.org/10.1002/(SICI)1521-1878(199808)20:8<652::AID-BIES8>3.0.CO;2-K

Klaassen, C. H. (2012). Evidence for genetic differentiation and variable recombination rates among Dutch population of the opportunistic human pathogen. Aspergillus fumigatus. Mol. Ecol, 21, 57-70. http://dx.doi.org/10.1111/j.1365-294X.2011.05364.x

Kolmer, J. A., Liu, J. Q., \& Sies, M. (1995). Virulence and molecular polymorphism in Puccinia recondite f.sp. tritici in Canada. Phytopathology, 85, 276-285. http://dx.doi.org/10.1094/Phyto-85-276

Krister, H. C., \& Miao, V. P. W. (1992). New modes of genetic change in filamentous fungi. Annu.Rev. phytopathol, 30, 131-152. http://dx.doi.org/10.1146/annurev.py.30.090192.001023

Leibenberg, M. M., \& Pretorius, Z. A. (1997). A review of angular leaf spot of common bean (Phaseolus Vulgaris L.). Afr. Plant Prot, 3, 81-106.

Louws, F. J., Rademaker, J. L. W., \& de Bruijn, D. (1999). The three Ds of PCR-based genomic analysis of phytobacteria: Diversity, detection, and disease diagnosis. Annual Review of Phyto-pathology, 37, 81-125. http://dx.doi.org/10.1146/annurev.phyto.37.1.81

Mahuku, G. S., Henr'iquez, M. A., Muñoz, J., \& Buruchara, R, A. (2002). Molecular markers dispute the existence of the Afro-Andean group of the bean angular leaf spot pathogen, Phaeoisariopsis griseola. Phytopathology, 92, 580-589. http://dx.doi.org/10.1094/PHYTO.2002.92.6.580

Mahuku, G. S., Iglesias, A. M., \& Jara, C. (2009). Genetics of angular leaf spot resistance in the Andean common bean accession G5686 and identification of markers linked to the resistance genes. Euphytica, 167, 381-396. http://dx.doi.org/10.1007/s10681-009-9897-4

Mahuku, G. S., Jara, C., Cuasquer, J. B., \& Castellanos, G. ( 2004a). Genetic variability within Phaeoisariopsis griseola from Central America and its implication for resistance breeding of common bean. Plant pathology, 51, 594-604. http://dx.doi.org/10.1046/j.1365-3059.2002.00742.x

Mahuku, S. (2004b). A simple extraction method suitable for PCR-based analysis of plant fungi and bacterial DNA. Plant molecular Biology Reporter, 22, 71-81. http://dx.doi.org/10.1007/BF02773351

McDonald, B. A., \& McDermott, J. M. (1993). Population genetics of plant pathogenic fungi. Biosciences, 43, 311-319. http://dx.doi.org/10.2307/1312063 
Ministry of Agriculture, Animal Industry and Fisheries (MAAIF). (2003). Operationalization of the Medium Term Plan for the Modernisation of Agriculture in Uganda, 1997-98, 200102, a Government Task Force Report, Entebbe, Uganda.

Mugisha, O. R. (2008). Uganda districts information handbook (expanded ed.). Kampala Uganda: Fountain Publishers.

Mwang'ombe, A. W., Wagara, I. N., Kimenju, J. W., \& Buruchara, R. A. (2007). Occurrence and Severity of Angular leaf spot of common bean in Kenya as influenced by geographical location, altitude and agroecological zones. Plant Pathology Journal, 6, 235-241. http://dx.doi.org/10.3923/ppj.2007.235.241

Namayanja, A., Buruchara, R., Mahuku, G., Rubaihayo, P., Kimani, P., Mayanja, S., \& Eyedu, H. (2006). Inheritance of resistance to angular leaf spot in common bean and validation of the utility of resistance linked markers for marker assisted selection out side the mapping population. Euphytica, 151(3), 361-369. http://dx.doi.org/10.1007/s10681-006-9158-8

Nei, M. (1973) Analysis of gene diversity in subdivided populations. Proc. Natl. Acad. Sci. U. S.A, 70, 3321-3323. http://dx.doi.org/10.1073/pnas.70.12.3321

Nietsche, S., Borem, A., Carvalho, G. A., Paula Junior, T. J., Fortes-Ferreira, C., \& Goncalves, E. (2001). Genetic diversity of Phaeoisariopsis griseola in the state of Minas Gerais, Brazil. Euphytica, 117, 77-84. http://dx.doi.org/10.1023/A:1004096421990

Nkonya, E. (2001). Bean Marketing in Uganda: Constraints and Opportunities. A paper Presented at the PABRA Millennium Synthesis, May 28 June 1, 2001, Arusha Tanzania International Food Policy Research Institute (IFPRI).

Opio, F., Ugen, M. A., Kyamanywa, S., David, S., \& Mugisa-Mutetikka, M. (2001). Beans. In J. K. Mukiibi (Ed.), Agriculture in Uganda: Crops II (pp. 162-191). Kampala, Uganda: Fountain Publishers.

Pastor-Corrales, M. A., Jara, C., \& Singh, S. (1998). Pathogenic variation in, source of, and breeding for resistance to Phaeoisariopsis griseola causing angular leaf spot in common bean. Euphytica, 103, 161-171. http://dx.doi.org/10.1023/A:1018350826591

Payne, R. W., Murray, D. A., Harding, S. A., Baird, D. B., \& Soutar, D. M. (2011). GenStat for windows (14th ed.) introduction. VSN International, Hemel.

Sartorato, A. (2000). Pathogenic variation in Phaeoisariopsis griseola from Brazil. Annu. Rep. Bean Improv. Coop, 43, 180-181. http://dx.doi.org/10.1590/S0100-41582002000100012

Sartorato, A. (2002). Identification of Phaeoisariopsis griseola pathotypes from five States in Brazil. Fitopatologia Brasileira , 27, 78-81. http://dx.doi.org/10.1111/j.1439-0434.2004.00858.x

Sartorato, A. (2004). Pathogenic Variability and Genetic Diversity of Phaeoisariopsis griseola isolates from two Counties in the State of Goias. Brazil J. Phytopathology, 152, 385-390. http://dx.doi.org/10.1016/j.pmpp.2006.10.001

Sebastian, A., Stenglein, I., Pedro, A., \& Balatti, A. (2006). Genetic diversity of Phaeoisariopsis griseola in Argentina as revealed by pathogenic and molecular markers. Physiological and Molecular Plant Pathology, 68, 158-167.

Sicard, D., Mickalakis, Y., Dron M., \& Neema C., (1993). Genetic diversity and pathogenic variation of Colletrotichum lindemuthianum in the three centers of diversity of its host, Phaseolus vulgaris. Phytopathology, 87, 807-813. http://dx.doi.org/10.1094/PHYTO.1997.87.8.807

Sneath, P. H., \& Sokal, R. R. (1973). Numerical Taxonomy. San Francisco; Free-man.

Stenglein, S. L. D., Ploper, O., Vizgarra, P., \& Balatti, P. (2003). Angular leaf spot: A disease caused by the fungus Phaeoisariopsis griseola (Sacc.) Ferraris on Phaseolus vulgaris L. Adv. Applied Microbiol, 52, 209-243. http://dx.doi.org/10.1016/S0065-2164(03)01009-8

Toxopeus, A. G. (1997). The erosion issue. In the integrated land and water management information system (Ilwis 2.1 for windows) Application guide.

Wagara, N., Mwang'ombe, A. W., Kimenju, J. W., Buruchara, R. A., \& Kimani, P. M. (2003). Pathogenic variability in Phaeoisariopsis griseola and response of bean germplasm to different races of the pathogen. African Crop Science Journal Society, 6, 352-357. 
Wortmann, C. S., Kirkby, R. A., Elude, C. A., \& Allen, D. J. (1998). Atlas of common bean (Phaseolus vulgaris L.) production in Africa. CIAT publication No. 297.

Zeigler, R. S., Scott, R. P., Leung., H., Bordeos, A. A., Kumar, J., \& Nelson, R. J. (1997). Evidence of parasexual exchange of DNA in the rice blast fungus challenges its exclusive clonality. Phytopathology, 87, 284-294. http://dx.doi.org/10.1094/PHYTO.1997.87.3.284

\section{Copyrights}

Copyright for this article is retained by the author(s), with first publication rights granted to the journal.

This is an open-access article distributed under the terms and conditions of the Creative Commons Attribution license (http://creativecommons.org/licenses/by/3.0/). 